\title{
Aa. Vv., Bulletin des Amis d'André Gide»
}

\section{Emanuele Kanceff}

\section{(2) OpenEdition}

\section{Journals}

\section{Edizione digitale}

URL: https://journals.openedition.org/studifrancesi/39771

DOI: 10.4000/studifrancesi.39771

ISSN: 2421-5856

\section{Editore}

Rosenberg \& Sellier

\section{Edizione cartacea}

Data di pubblicazione: 1 décembre 2004

Paginazione: 409

ISSN: 0039-2944

\section{Notizia bibliografica digitale}

Emanuele Kanceff, «Aa. VV., Bulletin des Amis d"André Gide»», Studi Francesi [Online], 143 (XLVIII | II) |

2004, online dal 30 novembre 2015, consultato il 19 mai 2021. URL: http://journals.openedition.org/ studifrancesi/39771 ; DOI: https://doi.org/10.4000/studifrancesi.39771

Questo documento è stato generato automaticamente il 19 mai 2021.

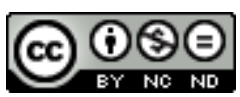

Studi Francesi è distribuita con Licenza Creative Commons Attribuzione - Non commerciale - Non opere derivate 4.0 Internazionale. 


\title{
Aa. Vv., Bulletin des Amis d'André Gide»
}

\author{
Emanuele Kanceff
}

\section{NOTIZIA}

«Bulletin des Amis d'André Gide», XXXVI e année, n. 139, vol. XXXI, juillet 2003, pp.

291-424.

1 Primo articolo di una serie in continuazione, evidentemente, è quello di Anton ALBLAS, L'Euvre instantanée: le Journal d'André Gide, I: Euvre-vie (pp. 299-310), che è una parte della pubblicazione quasi integrale della tesi che Alblas ha sostenuto in Australia nel dicembre 2001 e che il «BAAG» si propone di presentare ai suoi lettori.

Degli altri articoli non possiamo che evocare autori e titoli: Thomas CAZENTRE, La légende cachée. Lecture et intertextualité virgilienne dans "L'Immoraliste" (pp. 311-332); Claude FOUCART, Wolfgang Cordan (1909-1966), un inconnu?(pp. 333-340); Hilary HUTCHINSON, Madeleine et André Gide: l'histoire d'une double influence (pp. 341-355).

3 A questi quattro saggi della prima parte del fascicolo si aggiunge l'interessante ritratto che Jean CLAUDE, Portrait de Jean Schlumberger d'après sa correspondance (inédite) avec Jacques Copeau (pp. 356-372) offre agli studiosi e la consueta sezione di Robert LEVESQUE, Journal (septembre-octobre 1944).

4 Seguono, come sempre, Les Dossiers de presse des livres d'André Gide: Journal (R. FERNANDEZ, Cl.-Edm. magnY, H. GUILlemin, Fr. AmbrièRe, Ém. henRiot, D. halévy, G. BATAILle), Les Nouvelles Nourritures (Les Sept, H. Rambaud).

5 Vengono infine le Lectures gidiennes e le consuete rubriche. 